\title{
O016. Does migraine follow benign paroxysmal torticollis?
}

\author{
Maria Chiara Bernucci ${ }^{1}$, Roberto Frusciante ${ }^{1}$, Alessandro Capuano ${ }^{1}$, Samuela Tarantino ${ }^{1}$, Federico Vigevano ${ }^{1}$, \\ Massimiliano Valeriani ${ }^{1,2^{*}}$
}

From Abstracts from the 1st Joint ANIRCEF-SISC Congress

Rome, Italy. 29-31 October 2015

\section{Background}

Migraine equivalents are clinical conditions which often involve children who do not complain of headache. They include abdominal migraine, motion sickness, limb pain, cyclical vomiting, benign paroxysmal vertigo, and benign paroxysmal torticollis (BPT). The aim of our study was to investigate whether children referred to us for BPT have developed migraine at a distance from our first observation.

\section{Methods}

Forty-one children were included in the study. Only 36 families could be contacted by phone, but 2 of them refused to answer our questionnaire. Therefore, the present results were obtained from 34 children (22 girls and 12 boys).

\section{Results}

Migraine could be diagnosed in 14 children (41\%), while the remaining 20 patients (59\%) did not complain of headache. At the moment of our interview, children who had developed migraine had a mean age of 5 years, while the mean age of non-migrainous children was 3.5 years. Among migraine children, $43 \%$ developed it when they were 4 years, $21 \%$ at the age of 3 , and $14 \%$ when they were 7 years old. The last three migraineurs developed migraine at the age of 5 years, 13 years and 18 months, respectively. Moreover, $55 \%$ of patients had developed other migraine equivalents. In particular, 73\% children had abdominal migraine, $55 \%$ vertigo, $45 \%$ limb pain, $27 \%$ motion sickness, $27 \%$ cyclical vomiting. As for the paroxysmal torticollis time course, two children have had only one event, one child had been still

\footnotetext{
* Correspondence: m.valeriani@tiscali.it

${ }^{1}$ Headache Centre, Ospedale Bambino Gesù, IRCCS, Rome, Italy

Full list of author information is available at the end of the article
}

presenting episodes of torticollis, while in the remaining patients the torticollis events had not occurred for some years.

\section{Conclusions}

Our findings suggest that migraine follows BPT in approximately half of the children within the age of 13 years. Moreover, BPT is often associated to other migraine equivalents. Considered all together, all these periodic syndromes increase the risk of developing migraine.

Written informed consent to publish was obtained from the patient(s).

\section{Authors' details}

${ }^{1}$ Headache Centre, Ospedale Bambino Gesù, IRCCS, Rome, Italy. ${ }^{2}$ Center for Sensory-Motor Interaction, Aalborg University, Aalborg, Denmark.

Published: 28 September 2015

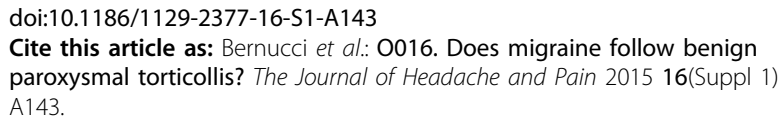

Cite this article as: Bernucci et al:: O016. Does migraine follow benign paroxysmal torticollis? The Journal of Headache and Pain 2015 16(Suppl 1): A143.

Submit your manuscript to a SpringerOpen ${ }^{\circ}$ journal and benefit from:

- Convenient online submission

- Rigorous peer review

- Immediate publication on acceptance

- Open access: articles freely available online

- High visibility within the field

- Retaining the copyright to your article

Submit your next manuscript at $>$ springeropen.com 